\title{
Evaluation of Doses-response and Combined Preventive Effects of Zinc and Vitamin D on Liver Toxicity Induced by Carbon Tetrachloride in Wistar Rats
}

\author{
Serge D. Kone ${ }^{1}$, Francis A. Yapo ${ }^{1, *}$, Goue Gnahoue ${ }^{2}$, Felix H. Yapi ${ }^{1}$ \\ ${ }^{1}$ Pharmacodynamics Biochemical Laboratory, UFR Biosciences, Felix Houphouet-Boigny University, Côte d'Ivoire \\ ${ }^{2}$ Laboratory of SVT, Higher Teacher Training School of Cote d'Ivoire, Cote d'Ivoire
}

Copyright $(2017$ by authors, all rights reserved. Authors agree that this article remains permanently open access under the terms of the Creative Commons Attribution License 4.0 International License

\begin{abstract}
Severe hepatic insufficiency caused by a toxic is a strong danger to the individual survival. Zinc and vitamin $\mathrm{D}$ are micronutrients involved in the prevention of several diseases. Our study was to evaluate the potential preventive effects of these micronutrients in hepatic toxicity induced by carbon tetrachloride $\left(\mathrm{CCl}_{4}\right)$ in rats. One hundred and fourteen (114) male rats were divided into 19 lots of 6 male rats each according to their body weight. Carbon tetrachloride $\left(\mathrm{CCl}_{4}\right)$ was used to induce hepatic toxicity in rats. The rats were treated respectively with 25,50 and $100 \mathrm{mg} / \mathrm{kg}$ of zinc and 6 , 12 and $24 \mu \mathrm{g} / \mathrm{kg}$ of Vitamin D and also with the combination of zinc and Vitamin D at the same concentrations. There was a significant increase in serum of ALT, AST without changing Total Protein level in the serum of rats treated with $\mathrm{CCl}_{4}$ compared to rats in the control lots. However, Zinc and Vitamin D supplementation caused a significant decrease in serum of ALT and AST activity without changing Total Protein concentration in the serum of rats. This study revealed that that zinc combined with Vitamin D could be a good protection against hepatic toxicity induced by chemicals.
\end{abstract}

Keywords Hepatoprotective, Zinc, Vitamin D, Hepatic Toxicity, Rat

\section{Introduction}

The liver is the organ that fulfills three major groups of vital functions: metabolic functions, detoxification functions and excretion functions [1]. It is therefore an indispensable organ for life. Severe hepatic impairment (acute or chronic) poses a serious risk to the individual with a survival rate of only about $20 \%$ [2]. It is reported that the standardized mortality rate from end-stage liver disease (i.e. cirrhosis) is higher than that for cardiovascular disease among patients with diabetes [3]. Chronic inflammation is involved in the development of hepatic disease [4, 5]. Otherwise, micronutrition can help prevent pathologies, some of which may be a sign of it.

Micronutrition is a recent concept advocated in prevention and in the treatment of acute or chronic pathologies [6]. It consists of "satisfying the micronutrient needs of an individual, through a diversified diet, associated if necessary with a personalized supplementation". In addition, micronutrition, like nutrition, aims to keep people healthy to protect the individual at risk, to optimize other treatments by reducing for example the side effects of medications, and to correct the disorders functional systems [7]. Micronutrients play no role in energy, but they are indispensables body functioning. These are vitamins, trace elements, minerals, essential fatty acids. Both zinc and vitamin D are important micro-nutrients for the body.

Zinc, is an essential component of a large number of enzymes participating in the synthesis and degradation of carbohydrates, lipids, proteins, and nucleic acids as well as metabolism of other micronutrients [8, 9]. It has also been reported that drug therapy or gene therapy that increases the serum zinc concentration can inhibit the progress of hepatic fibrosis [10].

Vitamin D is a fat-soluble, which is an essential micronutrient with major implications for human health. The biologically active form of vitamin $\mathrm{D}$ is $1,25-(\mathrm{OH})_{2} \mathrm{D}_{3}$ [11]. Vitamin D receptors are widely distributed in more than 38 tissues [12]. Macrophages and dendrite cells constitutively express vitamin D receptors which indicates plays an important role in regulating the inflammatory response [13]. Vitamin D is widely known for its role in the development and maintenance of bone tissue, as well as in the maintenance of calcium and phosphorus homeostasis. Studies were reported that vitamin D played an important role in decreasing the risk of type 2 diabetes [14], metabolic syndrome [15] and cardiovascular diseases [16]. However, 
the study of zinc and vitamin D effects and their combination in the prevention of liver toxicity remains unknown.

The aim of this study was to evaluate the preventive effects of zinc and vitamin D on liver markers in hepatic toxicity induced by carbon tetrachloride $\left(\mathrm{CCl}_{4}\right)$ in Wistar rats.

\section{Materials and Methods}

\subsection{Animal Material}

The animal species chosen for this study was the male Wistar albino rat. The rats were bred in the animal facility of Higher Normal School (ENS) at room temperature. In these premises, the photoperiod was 12 hours and the animals had free access to water and food. 114 male rats, aged 7-8 weeks, weighing approximately 200 to $230 \mathrm{~g}$ were used for the experiments. The selected rats had not been used for previous studies.

\subsection{Chemicals}

- Carbon tetrachloride was purchased from Sigma, Aldrich (USA).

- $\quad$ Zinc was purchased from Walmark (France, 02-2019) in the form of a bottle containing 30 tablets of $15 \mathrm{mg}$ of Zinc.

- Vitamin D one ampoule (2 ml) of dose 100,000 IU (CRINEX, France, 05-2018)

- $\quad \mathrm{NaCl}[0,9 \%]$ (Baxter, Belgique)

- The products of ALT (Alanine Aminotransferase) and AST (Aspartate Aminotransferase) used were supplied as reagents for "COBAS Integras 400 plus" by Roche Diagnostics ${ }^{\circledR}$ (Mannheim, Germany).

\subsection{Methods}

\subsubsection{Preparation of Solutions}

- Carbon tetrachloride $\left(\mathrm{CCl}_{4}\right)$ at a dose of $3 \mathrm{ml} / \mathrm{kg}$ was dissolved in an equal volume of olive oil rather than $50 \%$. It was administered intraperitoneally by injection of intoxication solution [17].

- $\quad 15 \mathrm{mg}$ tablet was dissolved in $5 \mathrm{ml}$ distilled water per kilogram bw [18] administered by gavage.

- Vitamin D (one dose) $2 \mathrm{ml}$ were dissolved in olive oil with $12 \mu \mathrm{g} / \mathrm{kg}$ bw [19] administered by gavage.

\subsubsection{Animal Treatment}

Animals were divided into 19 lots of 6 rats each $(n=6)$. The duration of experiment was for 14 days. The treatments are carried out every day at the same hour during the experimental period. Liver damage was achieved by injecting $3 \mathrm{ml} / \mathrm{kg}$ of $\mathrm{CCl}_{4}$ intraperitoneally on the 14 th day of feeding the animals in groups 4 to 19 with zinc and vitamin D.

\subsubsection{Treatment of Control Lots}

Lot 1: received $\mathrm{NaCl} 9 \%$ at $1 \mathrm{ml}$ by gavage over fourteen days (Normal control).

Lot 2: received $0.3 \mathrm{~mL}$ of olive oil by gavage over fourteen days.

Lot 3: received $1 \mathrm{ml}$ of $\mathrm{NaCl} 9 \%$ and $0,3 \mathrm{ml}$ of olive oil by gavage over fourteen days.

Lot 4: were administered with $\mathrm{CCl}_{4}$ only at $3 \mathrm{ml} / \mathrm{kg}$ body weight of $50 \%$ dissolved in olive oil intraperitoneally (ip) the $14^{\text {th }}$ day of treatment (Negative Control).

2.3.2.2. Treatment with Different Doses of Zinc (25, 50 and $100 \mathrm{mg} / \mathrm{kg} \mathrm{bw}$ ) by Gavage over Fourteen Days Followed by $\mathrm{CCl}_{4}(3 \mathrm{ml} / \mathrm{kg}$ of $50 \%)$ by Intraperitoneal Injection the $14^{\text {th }}$ day

Lot 5: received $25 \mathrm{mg} / \mathrm{kg}$ of zinc followed by $\mathrm{CCl}_{4}$ : $\mathrm{Zn} 25$ $+\mathrm{CCl}_{4}$

Lot 6: received $50 \mathrm{mg} / \mathrm{kg}$ of zinc followed by $\mathrm{CCl}_{4}$ : $\mathrm{Zn} 50$ $+\mathrm{CCl}_{4}$

Lot 7: received $100 \mathrm{mg} / \mathrm{kg}$ of zinc by followed by $\mathrm{CCl}_{4}$ : $\left(\mathrm{Zn} 100+\mathrm{CCl}_{4}\right)$

\subsubsection{Treatment with Different Doses of Vitamin D $(6,12$} and $24 \mu \mathrm{g} / \mathrm{kg}$ ) by Gavage over Fourteen Days Followed by $\mathrm{CCl}_{4}(3 \mathrm{ml} / \mathrm{kg}$ of $50 \%)$ by Intraperitoneal Injection the $14^{\text {th }}$ day

Lot 8: received $6 \mu \mathrm{g} / \mathrm{kg}$ of vitamin D followed by $\mathrm{CCl}_{4}$ : $\left(\mathrm{VD} 6+\mathrm{CCl}_{4}\right)$

Lot 9: received $12 \mu \mathrm{g} / \mathrm{kg}$ of vitamin $\mathrm{D}$ followed by $\mathrm{CCl}_{4}$ : $\left(\mathrm{VD} 12+\mathrm{CCl}_{4}\right)$

Lot 10: received $24 \mu \mathrm{g} / \mathrm{kg}$ of vitamin D followed by $\mathrm{CCl}_{4}$ : $\left(\mathrm{VD} 24+\mathrm{CCl}_{4}\right)$

2.3.2.4. Treatment with Combination of Vitamin $\mathrm{D}$ and $\mathrm{Zn}$ by Gavage over Fourteen Days Followed by $\mathrm{CCl}_{4}(3$ $\mathrm{ml} / \mathrm{kg}$ of $50 \%$ ) by Intraperitoneal Injection the $14^{\text {th }}$ day

Lot 11: received $25 \mathrm{mg} / \mathrm{kg}$ of zinc $+6 \mu \mathrm{g} / \mathrm{kg}$ of vitamin D followed by $\mathrm{CCl}_{4}: \mathrm{Zn} 25+\mathrm{VD} 6+\mathrm{CCl}_{4}$

Lot 12: received $25 \mathrm{mg} / \mathrm{kg}$ of zinc $+12 \mu \mathrm{g} / \mathrm{kg}$ of vitamin D followed by $\mathrm{CCl}_{4}: \mathrm{Zn} 25+\mathrm{VD} 12+\mathrm{CCl}_{4}$

Lot 13: received $25 \mathrm{mg} / \mathrm{kg}$ of zinc $+24 \mu \mathrm{g} / \mathrm{kg}$ of vitamin D followed by $\mathrm{CCl}_{4}: \mathrm{Zn} 25+\mathrm{VD} 24+\mathrm{CCl}_{4}$

Lot 14: received $50 \mathrm{mg} / \mathrm{kg}$ of zinc $+6 \mu \mathrm{g} / \mathrm{kg}$ of vitamin D followed by $\mathrm{CCl}_{4}: \mathrm{Zn} 50+\mathrm{VD} 6+\mathrm{CCl}_{4}$

Lot 15: received $50 \mathrm{mg} / \mathrm{kg}$ of zinc $+12 \mu \mathrm{g} / \mathrm{kg}$ of vitamin D followed by $\mathrm{CCl}_{4}$ : $\mathrm{Zn} 50+\mathrm{VD} 12+\mathrm{CCl}_{4}$

Lot 16: received $50 \mathrm{mg} / \mathrm{kg}$ of zinc $+24 \mu \mathrm{g} / \mathrm{kg}$ of vitamin D followed by $\mathrm{CCl}_{4}$ : $\mathrm{Zn} 50+\mathrm{VD} 24+\mathrm{CCl}_{4}$

Lot 17: received $100 \mathrm{mg} / \mathrm{kg}$ of zinc $+6 \mu \mathrm{g} / \mathrm{kg}$ of vitamin D followed by $\mathrm{CCl}_{4}$ : $\mathrm{Zn} 100+\mathrm{VD} 6+\mathrm{CCl}_{4}$

Lot 18: received $100 \mathrm{mg} / \mathrm{kg}$ of zinc $+12 \mu \mathrm{g} / \mathrm{kg}$ of vitamin $\mathrm{D}$ followed by $\mathrm{CCl}_{4}: \mathrm{Zn} 100+\mathrm{VD} 12+\mathrm{CCl}_{4}$

Lot 19: received $100 \mathrm{mg} / \mathrm{kg}$ of zinc $+24 \mu \mathrm{g} / \mathrm{kg}$ of vitamin D followed by $\mathrm{CCl}_{4}: \mathrm{Zn} 100+\mathrm{VD} 24+\mathrm{CCl}_{4}$ 


\subsubsection{Collection of Blood Samples}

All test animals were euthanized 24 hours after the last treatment in $14^{\text {th }}$ day. Also blood of each animal was taken (puncture of the orbital sinus) in a tube without anticoagulant, for metering the biochemical parameters.

\subsubsection{Biochemical Study}

Blood samples collected in anticoagulant-free tubes were centrifuged at $3000 \mathrm{rev} / \mathrm{min}$ for 15 minutes. The collected sera were used to measure the biochemical parameters namely: alanine amino transferase (ALT), the aspartate aminotransferase (AST) and total protein with the Cobas Integra 400 Plus (Roche diagnostic, Germany) in Ivory Coast Pasteur Institute.

\subsubsection{Statistical Analysis}

Graph Pad 5.1 was used for statistical analyses. Data were expressed as mean $\pm \mathrm{SD}$. Mean values of the different lots were compared using a one-way analysis of variance (ANOVA) with Dunnett test. If $\mathrm{p}<0.05$, the difference between the values was considered significant.

\section{Results}

\subsection{Effects of zinc and Carbon Tetrachloride $\left(\mathrm{CCl}_{4}\right)$ on Liver Markers}

The results in Figures $1 \mathrm{~A}$ and $1 \mathrm{~B}$ showed that the administration of $\mathrm{CCl}_{4}$ induced a significant increase $(\mathrm{p}<0.05)$ in the activity of ALAT and ASAT compared to the control lot $\mathrm{NaCl} 0.9 \%$. However, this high enzyme activity induced by $\mathrm{CCl}_{4}$ was significantly inhibited $(\mathrm{p}<0.05)$ by Zinc concentrations $(25,50$ and $100 \mathrm{mg} / \mathrm{kg}$ ). The values of the enzymatic activity of AST and ALT in rats pretreated with $\mathrm{Zn}$ are compatible with those of the rats of the control group $(\mathrm{NaCl} 0.9 \%)$ (Figures $1 \mathrm{~A}$ and $1 \mathrm{~B}$ ). For the total protein concentration both $\mathrm{CCl}_{4}$ and zinc pretreatment did not induce a significant variation from the values in rats of the control groups ( $\mathrm{NaCl} 0.9 \%$ and Olive oil) as shown in figure 1C.
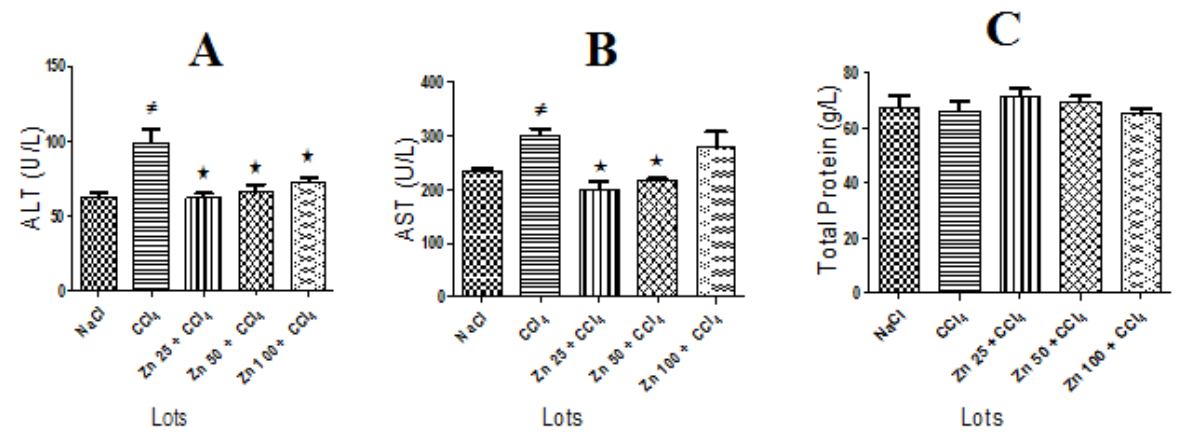

A: effects on ALT activity

B: effects on AST activity

C: effects on Total protein concentration

ALT: alanine aminotransferase, AST: aspartate aminotransferase, Total Protein,

Nacl: sodium chloride, $\mathrm{CCl}_{4}$ : carbon tetrachloride, $\mathrm{Zn}$ : zinc, VD: vitamin $\mathrm{D}, \mathrm{n}=6 / \mathrm{lot}$

$\neq$, *: $(\mathrm{P}<0.05)$ : statistically significant $\neq:(\mathrm{p}<0.05)$ vs $\mathrm{NaCl} *$ : $(\mathrm{p}<0.05)$ vs $\mathrm{CCl}_{4}$

Figure 1. Effect of Zinc and $\mathrm{CCl}_{4}$ administration on liver markers level in Wistar rats

A

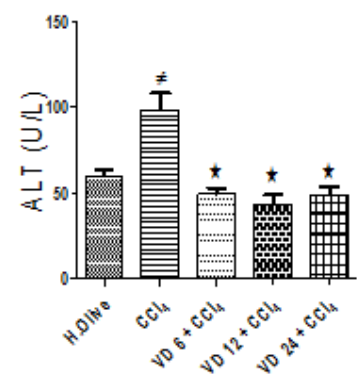

Lots
B

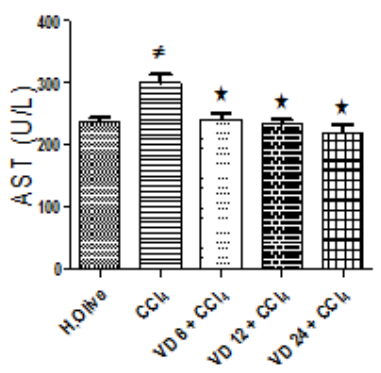

Lots

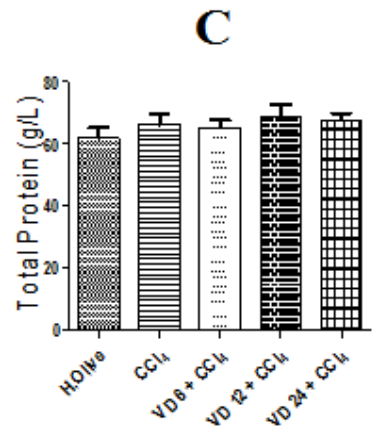

Lots

A: effects on ALT activity

B: effects on AST activity

C: effects on Total protein concentration

ALT: alanine aminotransferase, AST: aspartate aminotransferase, total protein,

H. Olive: Olive Oil, $\mathrm{CCl}_{4}$ : carbon tetrachloride, $\mathrm{Zn}$ : zinc, VD: vitamin $\mathrm{D}, \mathrm{n}=6 / \mathrm{lot}$

$\neq$, *: $(\mathrm{P}<0.05)$ : statistically significant $\neq:(\mathrm{p}<0.05)$ vs $\mathrm{H}$. Olive *: $(\mathrm{p}<0.05) \mathrm{vs} \mathrm{CCl}_{4}$

Figure 2. Effect of Vitamin $\mathrm{D}$ and $\mathrm{CCl}_{4}$ administration on liver markers level in Wistar Rats 


\subsection{Effects of Vitamin D and Carbon Tetrachloride $\left(\mathrm{CCl}_{4}\right)$ on Liver Markers}

Carbon tetrachloride $\left(\mathrm{CCl}_{4}\right)$ administration caused significant $(p<0.05)$ increase in the serum levels of the ALT, AST compared to the control lot Olive oil (figures 2A and 2B). However, treatment with low or high administration dose of vitamin D $(6,12$ and $24 \mu \mathrm{g} / \mathrm{kg})$ caused no significant change on the serum levels of enzymes compared to control lot treated by Olive oil after $\mathrm{CCl}_{4}$ administration but its induced a significant $(\mathrm{p}<0.05)$ decrease in the serum levels of hepatic enzymes compared to control lot treated with only $\mathrm{CCl}_{4}$ (figures 2A and 2B). There was no significant ( $\mathrm{p}>0.05$ ) change on the serum concentration of Total Protein in the lots administered with low or high dose of vitamin $\mathrm{D}$ when compared to the control lots (Olive oil and $\mathrm{CCl}_{4}$ alone) as shown in (Figure 2C).

\subsection{Combined Effects of Zinc and Vitamin D on Liver Markers}

The Figure 3 indicated a fixation of each concentration of zinc when a variation of vitamin $\mathrm{D}$ concentration was observed as represented in Figure 3. The results showed that $25 \mathrm{mg} / \mathrm{kg}$ bw of zinc combined respectively with $6 ; 12$ and $24 \mu \mathrm{g} / \mathrm{kg}$ of vitamin D was the best combination that reduced the level of parameters ALT and AST. In fact, this combination induced a low activity of hepatic enzymes as compared to others combinations presented by $\mathrm{Zn} 25$ curve below from the others graphs (Figure 3A and 3B). The best association observed on Total Protein concentration was 25 $\mathrm{mg} / \mathrm{kg}$ of zinc with 12 and $24 \mu \mathrm{g} / \mathrm{kg}$ of vitamin D. This combination increased in the serum concentration of Total Protein as compared to others combinations represented by $\mathrm{Zn} 25$ curve above others graphs (figures $3 \mathrm{C}$ ). In addition, liver is protected by association of zinc $(25 \mathrm{mg} / \mathrm{kg})$ and vitamin D $(12 ; 24 \mu \mathrm{g} / \mathrm{kg})$.

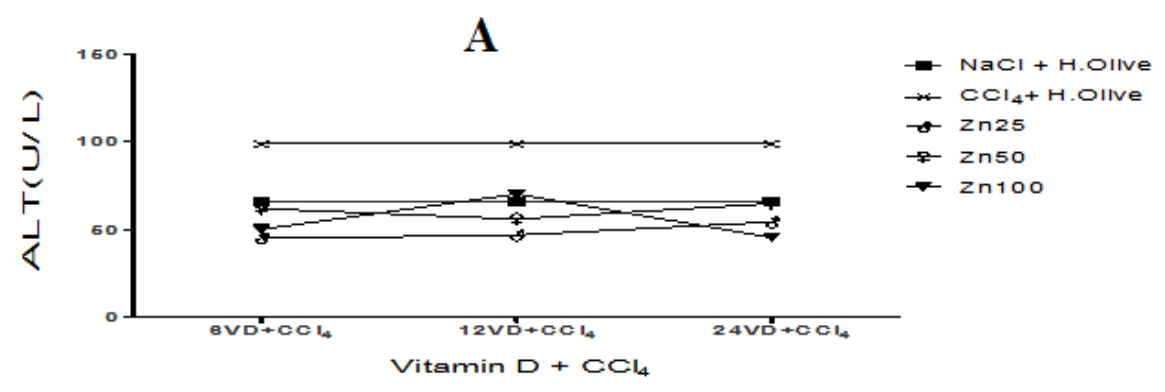

B
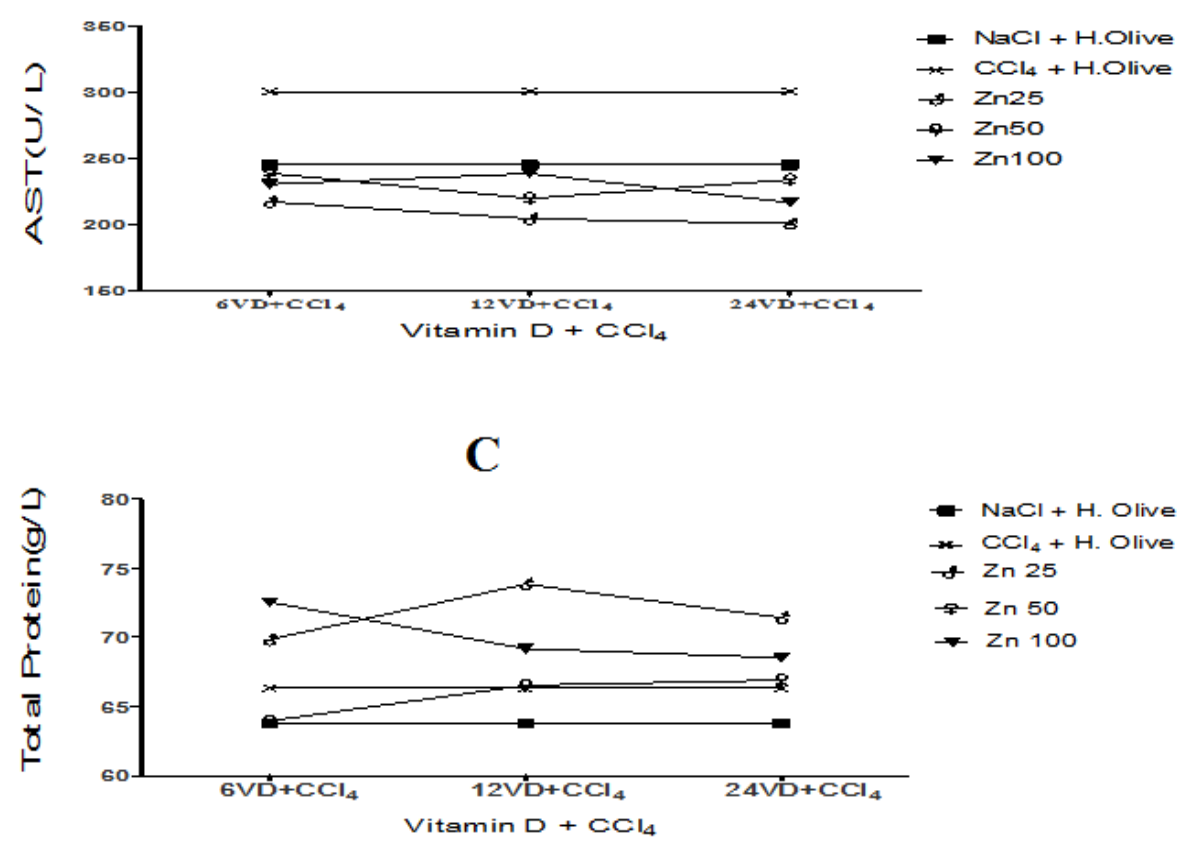

A: effects on ALT activity

B: effects on AST activity

C: effects on Total protein concentration

ALT: alanine aminotransferase, AST: aspartate aminotransferase, Total Protein,

Nacl: sodium chloride, $\mathrm{H}$. Olive: Olive Oil, $\mathrm{CCl}_{4}$ : carbon tetrachloride, $\mathrm{Zn}$ : zinc, VD: vitamin D, n=6/lot

Figure 3. Effect of Vitamin D and Zinc variation on liver markers in Wistar rats 


\section{Discussion}

The aim of our study was to evaluate the possible protective effects of zinc and vitamin D supplementation on liver functions in experimentally-induced hepatic damage in male albino rats. It was designed to denote the hepatoprotective activity of alimentation micronutrients. Intraperitoneal injection of Carbon tetrachloride $\left(\mathrm{CCl}_{4}\right)$ caused hepatic dysfunction. $\mathrm{CCl}_{4}$ induced a significant increase in liver enzyme activity such as ALAT and ASAT versus non-significant increase in total protein concentration. In fact, liver dysfunction is characterized by alteration in serum levels of liver enzymes and metabolic products [20]. The elevation in the liver marker enzyme was confirmed previous reports on the hepatotoxicity of $\mathrm{CCl}_{4}$ administration [21]. In this study, a significant elevation of transaminases (ALT and AST) activity in rats treated with $\mathrm{CCl}_{4}$ alone was observed as compared to normal control lot treated with $\mathrm{NaCl}$. The elevation of maker enzymes reported in this study is the same to the findings of [22] who observed significant hepatic damage in rats treated with single dose of $\mathrm{CCl}_{4}$.

The efficacy of any hepatoprotective drug is indeed dependent on its capability of either reducing the harmful effects or in maintaining the normal hepatic physiological mechanism which have been imbalanced by a hepatotoxin. It is in this perspective that this study was interested to the preventive effects of zinc and vitamin $\mathrm{D}$ supplementation in hepatic damage due to liver toxicity. In fact, Zinc is a known fundamental component of the endogenous enzymatic antioxidant system with antioxidant properties playing an essential role in cell membrane integrity and functions in many aspects of cellular metabolism [23]. Results of the present study showed significant reduction of the ALT and AST activity without significant effect on total protein with the preventive administration of zinc. These results were compatible with those of [24] who reported that after one month of zinc therapy, the mean serum ALT, AST and gamma glutamyl transpeptidase (GGT) levels dropped significantly. It is important to indicate that zinc is not only required for cell-mediated immunity, but also an effective antioxidant and anti-inflammatory agent [25]. It has reported by [26] that antioxidant substances can prevent liver damage induced by thyroid dysfunction.

Vitamin D is one of the fat-soluble vitamins which is activated partly in liver and is from endogenous biosynthesis in skin cells by ultraviolet radiation from sunlight and dietary sources. Carbon tetrachloride $\left(\mathrm{CCl}_{4}\right)$ administration induced hepatic damages. These damages were observed through the increasing of transaminases activity level in serum. The increasing evidence suggests that the circulating concentration of vitamin D was negatively associated with the risk of liver disease [27] and with the increasing severity of liver disease, the expression of hepatic pro-inflammatory cytokines also increased [28]. In the present study, rat lots were treated with vitamin D supplementation to prevent for
14 days. In addition, rats treated with $\mathrm{CCl}_{4}$ alone increased transaminase activity in serum. In the lots pre-treated with vitamin $\mathrm{D}$, the results indicated significant decreasing level in serum of ALT and AST when $\mathrm{CCl}_{4}$ was administrated. These results were confirmed by [29] who showed that serum ALT and AST activity were extremely elevated in rats of diabetic melittus group (DM) when in the vitamin D group, $1,25-(\mathrm{OH})_{2} \mathrm{D}_{3}$ treatment significantly lowered serum activity of ALT and AST compared with the DM group. All concentrations of vitamin D $(6,12$ and $24 \mu \mathrm{g} / \mathrm{kg})$ tested in the present study reduced these parameters. These vitamin D concentrations can contribute to liver protection. It was reported that $1,25-(\mathrm{OH})_{2} \mathrm{D}_{3}$ has protective effects on liver of diabetic rat by modulating inflammation and lipid metabolism [29].

The present study was realized to prevent liver toxicity. Indeed, it was important to find the best association of zinc and vitamin $\mathrm{D}$ which could prevent hepatic damage. To have beneficial effect on liver toxicity, this study has associated micronutrients as zinc and vitamin D. Moreover, the elevation of transaminases activity in serum of rats treated with $100 \mathrm{mg} / \mathrm{kg}$ of zinc was observed. Jansen et al., [30] have demonstrated that elevated concentration of zinc $(100 \mathrm{mg} / \mathrm{kg})$ induced pancreatic beta-cells destruction of human body. Vitamin $\mathrm{D}$ and zinc combination has decreased or attenuated toxic effects of $\mathrm{CCl}_{4}$ that we have observed. Vitamin D has played a role of modulator in zinc action by regulating zinc effect. Motiwala and Wang [31] have shown that vitamin D modulates lipid metabolism by decreasing the triglyceride level in overweight subjects' serum. Following the possible combinations in this study, the best were $25 \mathrm{mg} / \mathrm{kg}$ zinc combined with $12 \mu \mathrm{g} / \mathrm{kg}$ and $24 \mu \mathrm{g} / \mathrm{kg}$ of vitamin D. Moreover, the best association indicated decreasing of liver enzymes (AST, ALT) activities, and then total protein concentration increased. According to [32], preventive hepatoprotective action of Curcuma longa (Zingiberaceae) showed that the decreasing activity of liver enzymes elevate by $\mathrm{CCl}_{4}$ and the increasing concentration of total protein and stress enzymes highly decreased by $\mathrm{CCl}_{4}$.

These results show that to obtain better effect with high doses of zinc, high concentration of vitamin D must be used because vitamin D attenuate zinc toxicity. Vitamin D and Zinc association is hepatoprotective.

\section{Conclusions}

At the end of our study, it is important to note that zinc oral supplementation with 25 to $50 \mathrm{mg} / \mathrm{kg}$ is beneficial for the intoxicated liver and at $100 \mathrm{mg} / \mathrm{kg}$ it has harmful effects on liver. The oral supplementation of Vitamin D which up to $24 \mu \mathrm{g} / \mathrm{kg}$, has a beneficial effect on the liver toxicity. This study has showed that the best combination is obtained with $25 \mathrm{mg} / \mathrm{kg}$ of Zinc combined with 12, $24 \mu \mathrm{g} / \mathrm{kg}$ of Vitamin D. Finally, this study suggests that zinc combined with vitamin D provides good protection of liver against hepatic toxicity. 


\section{Acknowledgements}

We express our gratitude to the Biosciences UFR precisely the Staff of pharmacodynamics Laboratory of Félix Houphouët Boigny University, Cocody-Abidjan (Ivory Coast). So we would like to thank M. Yapi Houphouët Félix and all the officials of the ENS (Superior Normal School) who helped us in this research.

\section{REFERENCES}

[1] K. Lehmann, S. Breitenstein and P.A. Clavien. "From Promethean to Modern Times," in Malignant Liver Tumors: Current and Emerging Therapies, 3rd edition, pp. 3-10, 2000.

[2] H.B.A.C. Stockmann. Ijzermans J.N.M. Prospects for the temporary treatment of acute liver failure. European Journal of Gastroenterology Hepatology, 14: 195-203, 2002

[3] S.A. Harrison. Liver Disease in Patients with Diabetes Mellitus. The Journal of Clinical Gastroenterology, 40: 68-76, 2006.

[4] H. Tilg. Cytokines and liver diseases. Canadian Journal of Gastroenterology, 15(10): 661-668, 2001.

[5] H. M. El-Emshaty, W. A. Nasif, and I. E. Mohamed. Serum Cytokine of IL-10 and IL-12 in Chronic Liver Disease: The Immune and Inflammatory Response. Disease Markers, 2015: $1-7,2015$.

[6] A. Shenkin. Micronutrients in health and disease. Postgraduate Medical Journal, 82(971): 559-567, 2006.

[7] B. Pourias. Nutrients, functional foods, health food: border products. NAFAS 3 (11):1761-5275, 2000.

[8] Ch.B. Devi, Th. Nandakishore, N. Sangeeta, G. Basar, N.O Devi, S.D. Jamir, M.A. Singh. Zinc in Human health. IOSR Journal of Dental and Medical Sciences (IOSR-JDMS), 13(7):18-23, 2014.

[9] M.A. Okasha, S.R. Samaha, S.M. Mohamed and A.A. Fouda. Effects of zinc supplementation on liver Functions in experimentally-induced hyperthyroidism in rats. Al-Azhar Assiut Medical Journal, 12(4): 320-339, 2014.

[10] T. Ishikawa. Can zinc enhance response interferon therapy for patients with HCV-related liver disease? World Journal of Gastroenterology, 18 (25): 3196-3200, 2012.

[11] M.F. Holick. Vitamin D: evolutionary, physiological and health perspectives. Current Drug Targets. 12(1):4-18, 2011.

[12] W.P. James. 22nd Marabou Symposium: The Changing Faces of Vitamin D. Nutrition Review. 66: 286-290; 2008.

[13] X. Palomer, J.M. Gonzalez-Clemente and F. Blanco-Vaca. Mauricio D. Role of vitamin D in the pathogenesis of type 2 diabetes mellitus. Diabetes Obese Metabolism. 10(3): 185-97, 2008

[14] S.S. Harris. Does vitamin D deficiency contribute to increased rates of cardiovascular disease and type 2 diabetes in African Americans? , The American journal of clinical nutrition.
93:1175S-1178S, 2011.

[15] V. Ganji, X. Zhang, N. Shaikh and V. Tangpricha. Serum 25-hydroxyvitamin D concentrations are associated with prevalence of metabolic syndrome and various cardiometabolic risk factors in US children and adolescents based on assay-adjusted serum 25-hydroxyvitamin D data from NHANES 2001-2006, The American journal of clinical nutrition, 94: 225-233, 2011.

[16] P. Anagnostis, V.G. Athyros, F. Adamidou, M. Florentin and A. Karagiannis. - Vitamin D and Cardiovascular Disease: A Novel Agent for Reducing Cardiovascular Risk? Current Vascular Pharmacology, 8(5): 720-730, 2010.

[17] O.B. Adewale, A.O. Adekeye, C.O. Akintayo, A. Onikanni and S. Sabiu. - Carbon tetrachloride (CCl4)-induced hepatic damage in experimental Sprague Dawley rats: Antioxidant potential of Xylopia aethiopica The Journal of Phytopharmacology; 3(2): 118-123, 2014.

[18] M. Piao, Y. Liu, T. Yu and Y. Lu Y. Zinc supplementation ameliorates ER stress and autophagy in liver in a rat model of type 2 diabetes mellitus. Biomedical Research, 27(3): 1-7, 2016

[19] R.P.D. Claudia, C.D.S.B. Patrícia, S.M. Barbalho, R.K. Quesada1, L.B. Cora, B.V.P. Izabella, M.A. Mariane. -Effect of Vitamin D Supplements on the Body Weight and Glycaemia in Wistar Rats, British Journal of Pharmaceutical Research 10(1): 1-8, 2016.

[20] A. Ajayi, F.R.E. Akhigbe. - Implication of altered thyroid state on liver function. Thyroid Research and Practice; 9: 84-87, 2012

[21] K.C. Patrick-Iwuanyanwu, M.O. Wegwu and J.K. Okiyi. Hepatoprotective effects of African locust bean and negro pepper in $\mathrm{CCl}_{4}$ induced liver damage on wistar albino rats. International Journal of Pharmacology, 6(5):744-749, 2010.

[22] O. Prakash, G.N. Singh, R.M. Singh, S.C. Mathur, M. Bajpai and S. Yadav. Protective effects of herbal formula against carbon tetrachloride-induced hepatoxicity. International Journal of Pharmacology 4: 282-286, 2008.

[23] A.S. Catania, C.R. Barros and S.R. Ferreira. Vitamins and minerals with antioxidant properties and cardio metabolic risk: controversies and perspectives. The Journal of clinical endocrinology and metabolism 53: 550-559, 2009.

[24] K. Abuduxikuer and J. Wang J. zinc mono-therapy in presymptomatic Chinese children with wilson disease: a single center, retrospective study. plos one, 9 (3): 924- 931, 2014.

[25] A.S. Prasad. Discovery of human zinc deficiency: Its impact on human health and disease. Advanced in Nutrition, 4: 176-190, 2013.

[26] R.J. Reiter, D.X. Tan, J.C. Mayo, R.M. Sainz and J. Leon. Melatonin as an antioxidant: biochemical mechanisms and pathophysiological implications in humans. Acta Biochemical Polonorum, 50: 1129-1146, 2003.

[27] E.J. Rhee, M.K. Kim, S.E. Park, C.Y. Park, K.H. Baek, W.Y. Lee, M.I. Kang, S.W. Park, S.W. Kim and K.W. Oh. High serum vitamin D levels reduce the risk for non-alcoholic fatty liver disease in healthy men independent of metabolic syndrome. Journal of Endocrinology, 60 (6): 743-752, 2013. 
[28] E. Salum, P. Kampus, M. Zilmer, J. Eha, M. Butlin, A.P. Avolio, T. Põdramägi, A. Arend, M. Aunapuu and J. Kals. Effect of vitamin $\mathrm{D}$ on aortic remodelling in streptozotocin-induced diabetes, Cardiovascular Diabetology. 11:58,2012.

[29] C. Ning, L. Guodong, V. Yang, Y. Zhang, R. Yu, Y. Wang and J. Zhu. Lipid metabolism and inflammation modulated by liver of diabetic rats, Lipids in Health Disease 14(31): 3-9, 2015.

[30] J.M. Jansen, A.G. Wanless, C.W. Seidel and E.L. Weiss. -Cbk1 regulation of the RNA-binding protein Ssd1 integrates cell fate with translational control. Current Biology 19 (24):2114-2120, 2009.

[31] C. Ning, L. Liu, G. Lv, Y. Yang, Y. Zhang, R. Yu, Y. Wang, and J. Zhu. Lipid metabolism and inflammation modulated by Vitamin D in liver of diabetic rats. Lipids in Health and Disease, 14: 31-39, 2015.

[32] R. Serairi, N. Msilini, S. Jameleddine, R. Ksouri. Preventive and curative effects of Curcuma Longa on carbon tetrachloride-induced hepatotoxicity in rats. Nutrition Clinique et Métabolisme, 28: S121, 2014. 